\title{
Fruit dragée formulated with reused solution from pineapple osmotic dehydration
}

\author{
Sílvia Pimentel Marconi Germer ${ }^{(1)}$, Gisele Marcondes Luz(2), Lidiane Bataglia da Silva ${ }^{(3)}$, \\ Marta Gomes da Silva ${ }^{(4)}$, Marcelo Antonio Morgano ${ }^{(4)}$ and Neliane Ferraz de Arruda Silveira ${ }^{(4)}$
}

\begin{abstract}
(1)Instituto de Tecnologia de Alimentos (Ital), Centro de Tecnologia de Frutas e Hortaliças, Avenida Brasil, no 2880, Caixa Postal 139, CEP 13078-170 Campinas, SP, Brazil. E-mail: sgermer@ital.sp.gov.br (2)Universidade Estadual de São Paulo, Escola Superior de Agricultura Luiz de Queiroz, Departamento de Agroindústria, Alimentos e Nutrição, Avenida Pádua Dias, no 11, Caixa Postal 9, CEP 13418-900 Piracicaba, SP, Brazil. E-mail: gisele.luz@usp.br (3)Ital, Centro de Tecnologia de Cereais e Chocolates, Avenida Brasil, no 2880, Caixa Postal 139, CEP 13078-170 Campinas, SP, Brazil. E-mail: lidiane.bataglia@ital.sp.gov.br ${ }^{(4)}$ Ital, Centro de Ciência e Qualidade de Alimentos, Avenida Brasil, no 2880, Caixa Postal 139, CEP 13078-170 Campinas, SP, Brazil. E-mail: martags@ital.sp.gov.br, morgano@ital.sp.gov.br, neliane@ital.sp.gov.br
\end{abstract}

\begin{abstract}
The objective of this work was to evaluate the reuse of sucrose syrup in pineapple (Ananas comosus) osmotic dehydration and the application of the spent solution in fruit dragée formulation. Osmotic dehydration trials were performed in five cycles $\left(65^{\circ} \mathrm{Brix} / 45^{\circ} \mathrm{C} / 3\right.$ hours), directly reusing the osmotic solution, with only one intermediate reconditioning step. Variations in osmotic solution properties and in dehydration parameters were observed, as well as a low microbial load in the system. The spent solution was rich in vitamin $\mathrm{C}$ (30 $\left.\mathrm{mg} 100 \mathrm{~g}^{-1}\right)$. Pineapple dragée covered with red fruits and acai powders were obtained with the reconditioned

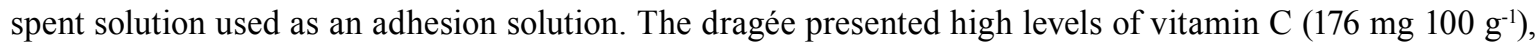

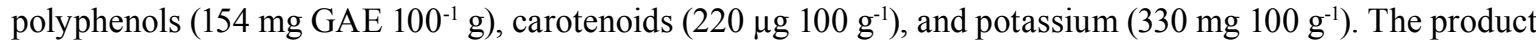
showed good sensory acceptance and purchase intention. Reusing sucrose syrup is technically feasible during pineapple osmotic dehydration, as is the application of the spent solution as an ingredient in fruit dragée production.
\end{abstract}

Index terms: Ananas comosus, drying, health foods, physicochemical properties, recycling, sucrose solution.

\section{Formulação de drageados de frutas com solução de reuso da desidratação osmótica de abacaxi}

Resumo - O objetivo deste trabalho foi avaliar o reuso do xarope de sacarose na desidratação osmótica de abacaxi (Ananas comosus) e o uso da solução final na formulação de drageados de frutas. Os ensaios de desidratação osmótica foram conduzidos em cinco ciclos $\left(65^{\circ} \mathrm{Brix} / 45^{\circ} \mathrm{C} / 3\right.$ horas $)$, com reuso direto da solução osmótica, com apenas uma etapa intermediária de recondicionamento. Foram observadas variações nas propriedades da solução osmótica e nos parâmetros da desidratação, bem como baixa carga microbiana do sistema. A solução final apresentou-se rica em vitamina C (30 mg $\left.100 \mathrm{~g} \mathrm{~g}^{-1}\right)$. Foram obtidos drageados de abacaxi cobertos com frutas vermelhas e açaí em pó com a solução final recondicionada como solução de aderência. O drageado apresentou níveis elevados de vitamina C $\left(176 \mathrm{mg} 100 \mathrm{~g} \mathrm{~g}^{-1}\right)$, polifenóis $(154 \mathrm{mg}$ GAE $\left.100 \mathrm{~g}^{-1}\right)$, carotenoides $\left(220 \mu \mathrm{g} 100 \mathrm{~g}^{-1}\right)$ e potássio $\left(330 \mathrm{mg} 100 \mathrm{~g} \mathrm{~g}^{-1}\right)$. O produto teve boa aceitação e intenção de compra. O reuso do xarope de sacarose é tecnicamente viável na desidratação osmótica de abacaxi, bem como a aplicação da solução final como ingrediente na produção de drageados de frutas.

Termos para indexação: Ananas comosus, secagem, alimentos saudáveis, propriedades físico-químicas, recirculação, solução de sacarose.

\section{Introduction}

Pineapple [Ananas comosus (L.) Merr.] is a muchconsumed tropical fruit, with a world production of around 25 million tons (FAO, 2016). The fruit is appreciated mainly due to its sensory aspects, although it has important nutritional properties such as high contents of calcium (22 mg $\left.100 \mathrm{~g}^{-1}\right)$, phosphorus $\left(13 \mathrm{mg} 100 \mathrm{~g}^{-1}\right)$, magnesium $\left(18 \mathrm{mg} 100 \mathrm{~g}^{-1}\right)$, and vitamin C (35 mg $100 \mathrm{~g}^{-1}$ ) (Lima et al., 2011).

Consumers are increasingly concerned about healthy eating, and their top choice has been fruit- 
based products because of their well-known nutritional value and naturalness (Sun-Waterhouse, 2011). Owing to this increasing interest, drying fruit is an option, and osmotic dehydration is an alternative pre-process. There are several studies on the performance of osmotic dehydration for fruits like guava, kiwi, pineapple, rambutan, among others (Peiró-Mena et al., 2007; Lowithun et al., 2009; Vieira et al., 2012; Nowacka et al., 2014).

This technique consists of immersing the raw material in a hypertonic solution for the partial removal of water, which takes place due to differences in osmotic pressure (Nowacka et al., 2014); however, since water removal is only partial, complementary conservation processes are required. Besides water, two other lower intensity flows are established in osmotic dehydration as the gain of solute from the solution to the fruit, and as the loss of natural soluble solids (pigments, acids, vitamins, and minerals) from the fruit to the solution. In general, due to the mild temperature and lack of oxygen, the osmotic dehydration process results in a good preservation of fruit characteristics (Chandra \& Kumari, 2015). However, in an osmotic cycle, the osmotic solution is greatly affected by the water and solute gains, leading to modifications in physicochemical properties and to a decrease in osmotic potential. Despite this, the osmotic solution should be reused in industrial processes, and can be applied by two general methods: direct reuse in some cycles, without reconditioning, even though it could affect the performance of the process; or after a reconditioning step (evaporation and/or solute addition) in order to restore the concentration, maintaining the conditions of the process (Dalla Rosa \& Giroux, 2001). In osmotic dehydration, reuse is important to achieve economic and environmental sustainability, considering input costs and the high organic load of the spent solution. Moreover, after several cycles of reuse, the enriched solution can still be applied as an ingredient in new formulations (Aachary \& Prapulla, 2009).

The osmotic solution may be used as an ingredient in the panning technology to produce pan-coated dragée, obtained by building up a shell by applying successive layers of coating to centers as they tumble in a revolving pan (Kitt, 2007). Syrup may also be included in the process, followed by the addition of dry material, aiming to reach a soft coat. Usually, adhesion solutions are syrups of sucrose and glucose, and, in theory, the osmotic solution may also be employed for this purpose. However, there are no known reports in the literature regarding this application.

The objective of this work was to evaluate the reuse of sucrose syrup in pineapple osmotic dehydration and the application of the spent solution in fruit dragée formulation.

\section{Materials and Methods}

Pineapple fruits of the 'Pérola' variety, purchased in a local market, during July and September 2014 (winter in Brazil), were stored at room temperature (approximately $25^{\circ} \mathrm{C}$ ) until maturity (approximately $12{ }^{\circ}$ Brix). The osmotic solution (OS) was prepared with refined sugar and distilled water (syrup). The ingredients added in the product formulation were: spray-dried red fruit pulp, including raspberry (Rubus idaeus L.), strawberry (Fragaria $\mathrm{x}$ ananassa), grape (Vitis vinifera L.), and blackberry (Rubus spp.), with 20\% maltodextrin (Centroflora Group, São Paulo, SP, Brazil); and freeze-dried acai (Euterpe oleracea Mart.) pulp (Liotécnica, Embu das Artes, SP, Brazil).

Five consecutive osmotic dehydration (OD) cycles were performed with sucrose syrup, using new syrup in the first cycle, then syrup obtained from the previous one in the subsequent cycles. New fruits were used in all cycles. The fruits were selected, washed, sanitized with $150 \mathrm{mg}$ sodium hypochlorite $\mathrm{L}^{-1}$, peeled, and cut into slices. Afterwards, the slices were cut into trapezoidal pieces $(2 \times 2 \times 1 \mathrm{~cm})$ with special knives, removing the core. Each OD cycle was performed in a $30-\mathrm{L}$ bath with a $10-\mathrm{L} \mathrm{min}^{-1}$ circulation pump, model 7306 (PolyScience, Niles, IL, EUA). The OD conditions were: syrup mass and fruit ratio of 10:1; syrup concentration of $65^{\circ}$ Brix; and process temperature and time of $45^{\circ} \mathrm{C}$ and 3 hours, respectively. The OD conditions were chosen based on Yadav \& Singh (2014) and on preliminary tests. At the end of cycles 3 and 5, the OS was reconditioned following the methodology described by Germer et al. (2012): sieving through a steel sieve (1 $\mathrm{mm}$ mesh); concentrating in a vacuum vat, model C055 (Indústria de Máquinas Mecamau São José, Espírito Santo do Pinhal, SP, Brazil) at 0.5 kgf $\mathrm{cm}^{-2}$, at approximately $70^{\circ} \mathrm{C}$; and adding new syrup in order to return to the original mass. At the end of each cycle, the osmodehydrated fruit (OF) was 
drained, rinsed in water, and gently blotted with tissue paper.

After each OD cycle, the OF was dried in a tray dryer with air circulation, model K13963 (Proctor \& Schwartz Electric Co., Philadelphia, PA, USA), at $65^{\circ} \mathrm{C}$, for approximately 5 hours, until reaching a

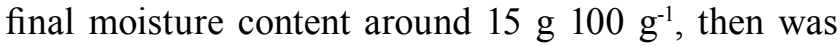
reserved for dragée processing. After the fifth cycle, the final syrup $\left(\mathrm{OS}_{\mathrm{f}}\right)$ was reconditioned, as previously described, in order to restore the original concentration. Then, the reconditioned final solution $\left(\mathrm{OS}_{\mathrm{rf}}\right)$ was frozen at $-18^{\circ} \mathrm{C}$, to better maintain its quality and to perform the subsequent step. The experiment was carried out in two replicates.

Analyses were performed in different cycles with fresh fruit (FF), OF, initial syrups (Si), and final syrup $\left(\mathrm{S}_{\mathrm{f}}\right)$. The parameters water loss $(\mathrm{WL})$ and solids incorporation (SI) were calculated during OD using the following equations: WL ( $\mathrm{g}$ water $100 \mathrm{~g}^{-1}$ initial mass $)=\left(\mathrm{U}_{\mathrm{i}} \mathrm{M}_{\mathrm{i}}-\mathrm{U}_{\mathrm{f}} \mathrm{M}_{\mathrm{f}}\right) / \mathrm{M}_{\mathrm{i}} \times 100$ and SI (g solute $100 \mathrm{~g}^{-1}$ initial mass $)=\left(\mathrm{ST}_{\mathrm{f}} \mathrm{M}_{\mathrm{f}}-\mathrm{ST}_{\mathrm{i}} \mathrm{M}_{\mathrm{i}}\right) / \mathrm{M}_{\mathrm{i}} \times 100$, in which $\mathrm{U}_{\mathrm{i}}$ is the initial moisture content; $\mathrm{M}_{\mathrm{i}}$ is the initial mass; $\mathrm{U}_{\mathrm{f}}$ is the final moisture content; $\mathrm{M}_{\mathrm{f}}$ is the final mass; $\mathrm{ST}_{\mathrm{f}}$ is the final total solids content; and $\mathrm{ST}_{\mathrm{i}}$ is the initial solids content.

Dried pineapple, obtained as previously described, was manually cut into pieces of $1.1 \times 1.3 \times 0.5 \mathrm{~cm}$ (approximately $1 \mathrm{~g}$ per unit) and used as centers in the panning process. The $\mathrm{OS}_{\mathrm{rf}}$, also determined as previously described, was used as an adhesion solution. Panning was conducted in a 5-L pilot revolving pan, model JAA 110E (Incal Máquinas Industriais e Caldeiraria Ltda., São Paulo, SP, Brazil). Successive layers of solution and fruit powder mixture were deposited on the surface of the centers to build up the coating. The fruit powder mixture consisted of $75 \mathrm{~g} 100 \mathrm{~g}^{-1}$

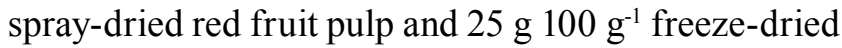
acai pulp. The $\mathrm{OS}_{\mathrm{rf}}$ was applied at a ratio of $20 \mathrm{~g} 100 \mathrm{~g}^{-1}$ dried pineapple. With the pan in movement $(40 \mathrm{rpm})$ and after solution distribution, the dry powder mixture was sprinkled directly onto the surface of the cut pieces at a concentration of $37{\mathrm{~g} 100 \mathrm{~g}^{-1}}^{-}$ dried pineapple. This procedure was repeated once again, totaling two cycles (10 min per cycle), aiming to achieve the desired coating ratio (1:0.7, center per coating). After that, final drying was performed in the tray dryer with air circulation, at $65^{\circ} \mathrm{C}$, for $40 \mathrm{~min}$, in order to obtain a crispier product. Process conditions were established according to preliminary tests. The quality of the obtained fruit dragée was evaluated by physicochemical analyses and a sensory test.

Soluble solid content was measured using the PAL-a digital refractometer (Atago CO., Ltd., Tokyo, Japan). Water activity was determined with the AquaLab Series 3TE hygrometer (Decagon Devices, Pullman, WA, USA) at $25^{\circ} \mathrm{C}$. The CR-300 chroma meter (Konica Minolta, Osaka, Japan) was employed for the color analyses, using the CIElab system ( $\mathrm{d}=0$ /D65 illuminant) to measure lightness $\left(\mathrm{L}^{*}=0\right.$ for black and $\mathrm{L}^{*}=100$ for white) and the chromaticity parameters a* (green [-] to red $[+]$ ) and $b^{*}$ (blue [-] to yellow $[+]$ ). The moisture content was determined in a vacuum oven until constant weight at $70^{\circ} \mathrm{C}$ (approximately $100 \mathrm{mmHg}$ ) (Horwitz \& Latimer, 2010), whereas the sugar content was obtained by the Munson \& Walker method (Horwitz \& Latimer, 2010). Titratable acidity was measured with the acidimetric method (Horwitz \& Latimer, 2010), and the $\mathrm{pH}$ with the DM-20 potentiometer (Digimed Instrumentação Analítica, São Paulo, SP, Brazil). Total phenolics and vitamin $\mathrm{C}$ contents were determined by Folin Ciocalteu's spectroscopic method (Benvenuti et al., 2004) and by the titration method (Benassi \& Antunes, 1988), respectively. The microbial load was obtained by yeast and mold counts (Downes \& Ito, 2001). Minerals were analyzed by inductively coupled plasma optical emission spectrometry (ICP-OES) using the Vista-MPX equipment (Varian, Inc., Agilent Technologies, Santa Clara, CA, USA). Carotenoids were evaluated by $\beta$-carotene quantification using high-performance liquid chromatography (HPLC) (Carvalho et al., 1992). All analyses were carried out at least in triplicate.

The obtained fruit dragée was assessed through the affective sensory test as to color, flavor, aroma, texture, and overall impression. The following nine-point hedonic scale was used to evaluate each attribute: 9, like extremely; 8 , like very much; 7, like moderately; 6 , like slightly; 5 , neither like nor dislike; 4, dislike slightly; 3 , dislike moderately; 2 , dislike very much; and 1, dislike extremely. A five-point scale was used to assess the purchase intent: 5 , definitely would buy; 4, probably would buy; 3 , maybe/maybe not; 2 , probably would not buy; and 1, definitely would not buy (Meilgaard et al., 2006). Consumers were also requested to describe what they most/least liked about the product. A total of 60 untrained subjects, both male 
and female, between the ages of 18 and 60, took part of the test. Each sample (six units) was served to the consumers in plastic cups labelled with random threedigit number codes, and water and unsalted crackers were also provided for rinsing.

The analytical results were statistically evaluated by the analysis of variance using the software Statistica, version 8.0 (TIBCO Software Inc., Palo Alto, CA, USA), and the separation of the means was determined by Tukey's test, at $5 \%$ probability.

\section{Results and Discussion}

The fruit properties changed with the OD process. When comparing fresh fruit and osmodehydrated fruit, an increase in the total sugar content was observed (Table 1), suggesting a migration of these compounds from the solution to the fruit during OD. In contrast, there was a decrease in the content of reducing sugars, indicating an important leaching flow from fruit to solution, in agreement with other studies (ValdezFragoso et al., 2002; Germer et al., 2012). The data also showed a significant decrease in vitamin $\mathrm{C}$ contents. According to Santos \& Silva (2008), the loss in vitamin C during fruit OD happens due to oxidation and leaching to the solution because of the high water solubility of the molecule. Losses in vitamin C (46\%) were reported during OD of guava (Psidium guajava L.) by Germer et al. (2016). Moreover, Peiró-Mena et al. (2007) found important losses of minerals, ranging from $40-60 \%$, during pineapple OD, which might be related to the high solubility of these elements. Regarding sodium, the use of sodium hypochlorite in cleaning the fruits could have affected the obtained results. However, the carotenoid contents did not differ significantly. These small losses could be attributed to the low solubility of carotenoids in aqueous solutions (Khoo et al., 2011). In contrast, Araya-Farias et al. (2014) observed significant losses in carotenoids during sea buckthorn (Hippophae rhamnoides L.) OD, which might be related to the higher OD time employed by the authors, of 6 hours. Similarly, the contents of phenolics did not differ significantly during pineapple OD. Blanda et al. (2008) detected the same behavior during the OD of apple. Kucner et al. (2013), however, verified losses in phenolics during blueberry OD, and related them to the higher process temperature applied $\left(60-70^{\circ} \mathrm{C}\right)$. In addition, color parameters did not differ significantly, a behavior that might be related to the low variation of carotenoids, which are the main pigments of pineapple (Rodriguez-Amaya, 2001).

Regarding the OS, the total soluble solids contents (TSS) decreased during OD, as expected with the gain of water (Table 2). The TSS continuously decreased until the end of the third cycle, but were re-established with the reconditioning step, decreasing again until the end of the trial. Consequently, the TSS of the Si were different at the different cycles, with a maximum variation of $6 \%$. Peiró-Mena et al. (2007) found $12 \%$ of variation in the TSS of the solution in a pineapple OD trial (15 cycles/syrup:fruit mass ratio of 20:1). This result might be due to the number of cycles employed and to the lack of sucrose syrup reconditioning.

Table 1. Mean values of the evaluated physicochemical properties of fresh fruit (FF) and osmodehydrated fruit (OF) throughout the pineapple (Ananas comosus) osmotic dehydration trial $^{(1)}$.

\begin{tabular}{|c|c|c|}
\hline Property & Fresh fruit & $\begin{array}{l}\text { Osmodehydrated } \\
\text { fruit }\end{array}$ \\
\hline Moisture content $\left(\mathrm{g} 100 \mathrm{~g}^{-1}\right)$ & $86.84 a$ & $70.55 \mathrm{~b}$ \\
\hline Total soluble solids ( $\left.{ }^{\circ} \mathrm{Brix}\right)$ & $11.78 \mathrm{a}$ & $30.44 \mathrm{~b}$ \\
\hline $\mathrm{pH}$ & $3.87 \mathrm{a}$ & $3.96 \mathrm{a}$ \\
\hline Water activity & $0.990 \mathrm{a}$ & $0.980 \mathrm{~b}$ \\
\hline Titratable acidity (g ca $\left.100 \mathrm{~g}^{-1}\right)$ & $0.550 \mathrm{a}$ & $0.490 \mathrm{~b}$ \\
\hline Total sugar $\left(\mathrm{g} 100 \mathrm{~g} \mathrm{db}^{-1}\right)$ & $73.04 \mathrm{a}$ & $87.94 \mathrm{~b}$ \\
\hline Reducing sugars (g $100 \mathrm{~g} \mathrm{db}^{-1}$ ) & $23.54 \mathrm{a}$ & $11.37 \mathrm{~b}$ \\
\hline Total carotenoids $\left(\mu \mathrm{g} 100 \mathrm{~g}^{-1}\right)^{(2)}$ & $72.21 \mathrm{a}$ & $75.15 \mathrm{a}$ \\
\hline Total polyphenols (mg GAE $100 \mathrm{~g}^{-1}$ ) & $48.49 \mathrm{a}$ & $53.37 \mathrm{a}$ \\
\hline Vitamin C (mg $\left.100 \mathrm{~g}^{-1}\right)$ & $53.46 \mathrm{a}$ & $43.06 \mathrm{~b}$ \\
\hline \multicolumn{3}{|l|}{ Color parameters } \\
\hline $\mathrm{L}^{*}$ & $54.41 \mathrm{a}$ & $52.94 \mathrm{a}$ \\
\hline$a^{*}$ & $-3.54 \mathrm{a}$ & $-3.50 \mathrm{a}$ \\
\hline $\mathrm{b}^{*}$ & $11.00 \mathrm{a}$ & $12.27 \mathrm{a}$ \\
\hline \multicolumn{3}{|l|}{ Mineral contents } \\
\hline Sodium (mg $100 \mathrm{~g}^{-1}$ ) & $1.09 \mathrm{a}$ & $4.23 b$ \\
\hline Calcium (mg $100 \mathrm{~g}^{-1}$ ) & $16.57 \mathrm{a}$ & $5.80 \mathrm{~b}$ \\
\hline Potassium (mg $\left.100 \mathrm{~g}^{-1}\right)$ & $134.67 \mathrm{a}$ & $18.38 b$ \\
\hline Copper (mg $100 \mathrm{~g}^{-1}$ ) & $0.08 \mathrm{a}$ & $0.01 \mathrm{~b}$ \\
\hline $\operatorname{Iron}\left(\mathrm{mg} 100 \mathrm{~g}^{-1}\right)$ & $0.27 \mathrm{a}$ & $0.05 \mathrm{a}$ \\
\hline Phosphorus (mg $100 \mathrm{~g}^{-1}$ ) & $7.89 \mathrm{a}$ & $0.75 b$ \\
\hline Magnesium (mg $\left.100 \mathrm{~g}^{-1}\right)$ & $10.54 \mathrm{a}$ & $1.39 \mathrm{~b}$ \\
\hline Manganese (mg $\left.100 \mathrm{~g}^{-1}\right)$ & $1.08 \mathrm{a}$ & $0.11 b$ \\
\hline Zinc $\left(\mathrm{mg} 100 \mathrm{~g}^{-1}\right)$ & $0.11 \mathrm{a}$ & $0.00 \mathrm{~b}$ \\
\hline
\end{tabular}

(1)Means followed by equal letters, in the lines, do not differ by Tukey's test, at $5 \%$ probability. ${ }^{(2)}$ Expressed as $\beta$-carotene. Mean of five cycles. 
Compared with the osmotic parameters, WL and SI showed variations of 17 and $20 \%$, respectively, between cycles. This result may be related to syrup dilution and to the consequent loss of osmotic potential. It should be pointed out that these differences are still acceptable in an industrial scale, since the inherent variability of the fruits requires continuous monitoring and adjusting in the drying process. However, Germer et al. (2016) reported lower differences, of around 5\%, in the parameters during the reuse of sucrose syrup in guava OD. Most likely, in this case, the operation conditions were maintained due to syrup reconditioning in each cycle.

The total titratable acidity of the solution increased during the trial, and the $\mathrm{pH}$ decreased (Table 3), reaching a value close to the fruit $\mathrm{pH}$ (Table 1). These results indicate that the solution gained fruit acids during reuse, with a consequent decrease in the pH. Germer et al. (2012), evaluating peach [Prunus persica (L.) Batsch] OD, observed a similar behavior. Regarding the color of the OS, there were small variations in the studied parameters during the trial: of approximately $1 \%$ for $L^{*}$, of approximately $5 \%$ for a*, and of approximately $5 \%$ for $b^{*}$. These results might be explained by the low water solubility of $\beta$-carotene, pineapple's main pigment, and by the high syrup:fruit mass ratio adopted (10:1), which diluted the solubilized pigments. Osorio et al. (2007) found higher differences in color parameters (16-33\%) during a three-cycle OD trial with Andes cherry (Rubus glaucus Benth.) (70 ${ }^{\circ} \mathrm{Brix} / 30^{\circ} \mathrm{C} / 24$ hours/ syrup:fruit mass ratio of 3:1). In this case, the sucrose syrup was not reconditioned, and the anthocyanin, the main fruit pigment, is a water-

Table 2. Total soluble solids contents (TSS) of initial $\left(\mathrm{S}_{\mathrm{i}}\right)$ and final $\left(\mathrm{S}_{\mathrm{f}}\right)$ syrups, as well as the parameters water loss (WL) and solids incorporation (SI) throughout the pineapple (Ananas comosus) osmotic dehydration trial ${ }^{(1)}$.

\begin{tabular}{lccccc}
\hline Cycles & \multicolumn{2}{c}{ TSS } & & \multicolumn{2}{c}{ Parameter } \\
\cline { 2 - 3 } \cline { 5 - 6 } & $\mathrm{S}_{\mathrm{i}}\left({ }^{\circ}\right.$ Brix $)$ & $\mathrm{S}_{\mathrm{f}}\left({ }^{\circ}\right.$ Brix $)$ & & WL $\left(\mathrm{g} 100 \mathrm{~g}^{-1}\right)$ & $\mathrm{SI}\left(\mathrm{g} 100 \mathrm{~g} \mathrm{~g}^{-1}\right)$ \\
\hline 1 & $64.70 \mathrm{a}$ & $62.50 \mathrm{a}$ & & $39.51 \mathrm{a}$ & $7.61 \mathrm{a}$ \\
2 & $62.70 \mathrm{~b}$ & $61.10 \mathrm{~b}$ & & $32.73 \mathrm{~b}$ & $7.26 \mathrm{ab}$ \\
3 & $61.30 \mathrm{c}$ & $60.60 \mathrm{bc}$ & & $35.07 \mathrm{c}$ & $6.04 \mathrm{~b}$ \\
4 & $66.00 \mathrm{~d}$ & $63.50 \mathrm{~d}$ & & $35.46 \mathrm{~cd}$ & $10.15 \mathrm{~cd}$ \\
5 & $64.00 \mathrm{e}$ & $62.50 \mathrm{a}$ & & $36.85 \mathrm{~d}$ & $9.29 \mathrm{~d}$ \\
\hline
\end{tabular}

(1)Means followed by equal letters, in the columns, do not differ by Tukey's test, at $5 \%$ probability. soluble compound, resulting in a greater concentration in the solution. Furthermore, there was a significant increase in the content of reducing sugars in the OS with reuse (Table 3), which might be attributed to the migration of natural fruit sugars to the solution. This result reinforces the previous discussion about the content of reducing sugars in the fruit during OD. Valdez-Fragoso et al. (2002) also noted an increase of around five times in the content of reducing sugars in the sucrose syrup throughout a five-cycle trial of apple OD. Similarly, a significant increase in vitamin $\mathrm{C}$ content was detected in the OS with reuse, reinforcing the previously observed behavior of the compound in the fruit. There was also a small increase in carotenoid contents, and the lipid solubility of these molecules seems to be the cause, as mentioned before. Germer et al. (2016), when reusing sucrose syrup in guava OD, reported a similar trend. Concerning the contents of phenolics, there were slight increases in the OS during

Table 3. Physicochemical properties of the initial syrup $\left(\mathrm{S}_{\mathrm{i}}\right)$ in three cycles of the pineapple (Ananas comosus) osmotic dehydration trial ${ }^{(1)}$.

\begin{tabular}{|c|c|c|c|}
\hline Property & Cycle 1 & Cycle 3 & Cycle 5 \\
\hline \multicolumn{4}{|l|}{ Physicochemical } \\
\hline $\mathrm{pH}$ & $7.38 \mathrm{a}$ & $5.08 \mathrm{~b}$ & $4.49 \mathrm{c}$ \\
\hline Water activity & $0.872 \mathrm{a}$ & $0.894 \mathrm{~b}$ & $0.872 \mathrm{c}$ \\
\hline Titratable acidity $\left(\mathrm{g}\right.$ ca $\left.100 \mathrm{~g}^{-1}\right)$ & $0.003 \mathrm{a}$ & $0.025 \mathrm{~b}$ & $0.059 \mathrm{c}$ \\
\hline Reducing sugars $\left({\left.\mathrm{g} 100 \mathrm{~g}^{-1}\right)}^{2}\right.$ & $1.31 \mathrm{a}$ & $1.16 \mathrm{~b}$ & $3.24 \mathrm{c}$ \\
\hline Total carotenoids ${ }^{(2)}\left(\mu \mathrm{g} 100 \mathrm{~g}^{-1}\right)$ & $0.15 \mathrm{a}$ & $0.30 \mathrm{~b}$ & $1.03 \mathrm{c}$ \\
\hline Total polyphenols (mg GAE $100 \mathrm{~g}^{-1}$ ) & $0.35 \mathrm{a}$ & $1.91 \mathrm{~b}$ & $2.91 \mathrm{c}$ \\
\hline Vitamin C (mg $\left.100 \mathrm{~g}^{-1}\right)$ & $3.93 \mathrm{a}$ & $12.43 \mathrm{~b}$ & $29.88 \mathrm{c}$ \\
\hline \multicolumn{4}{|l|}{ Color parameters } \\
\hline $\mathrm{L}^{*}$ & $39.71 \mathrm{a}$ & $40.86 \mathrm{~b}$ & $39.91 \mathrm{a}$ \\
\hline$a^{*}$ & $-1.37 \mathrm{a}$ & $-1.36 b$ & $-1.42 \mathrm{ab}$ \\
\hline $\mathrm{b}^{*}$ & $5.05 \mathrm{a}$ & $3.12 b$ & $4.79 \mathrm{a}$ \\
\hline \multicolumn{4}{|l|}{ Mineral contents } \\
\hline Sodium (mg $100 \mathrm{~g}^{-1}$ & $4.17 \mathrm{a}$ & $3.98 \mathrm{a}$ & $4.72 \mathrm{a}$ \\
\hline Calcium (mg $100 \mathrm{~g}^{-1}$ ) & $5.17 \mathrm{a}$ & $5.71 \mathrm{ab}$ & $6.54 \mathrm{~b}$ \\
\hline Potassium (mg $\left.100 \mathrm{~g}^{-1}\right)$ & $6.34 \mathrm{a}$ & $12.03 \mathrm{a}$ & $18.70 \mathrm{~b}$ \\
\hline Copper (mg $\left.100 \mathrm{~g}^{-1}\right)$ & $0.01 \mathrm{a}$ & $0.01 \mathrm{a}$ & $0.01 \mathrm{a}$ \\
\hline Iron $\left(\mathrm{mg} 100 \mathrm{~g}^{-1}\right)$ & $0.02 \mathrm{a}$ & $0.04 \mathrm{ab}$ & $0.05 b$ \\
\hline Phosphorus (mg $100 \mathrm{~g}^{-1}$ ) & $0.10 \mathrm{a}$ & $0.462 b$ & $0.77 \mathrm{c}$ \\
\hline Magnesium (mg $\left.100 \mathrm{~g}^{-1}\right)$ & $0.88 \mathrm{a}$ & $1.25 \mathrm{~b}$ & $1.50 \mathrm{~b}$ \\
\hline Manganese (mg $\left.100 \mathrm{~g}^{-1}\right)$ & $0.002 \mathrm{a}$ & $0.09 \mathrm{~b}$ & $0.14 \mathrm{c}$ \\
\hline Zinc (mg $\left.100 \mathrm{~g}^{-1}\right)$ & $0.00 \mathrm{a}$ & $0.00 \mathrm{a}$ & $0.00 \mathrm{a}$ \\
\hline
\end{tabular}


the reuse trial, although, in the fruit, as previously highlighted, there were no significant differences. The reason for this behavior might be the migration of phenolic compounds from the fruit to the solution, as verified by Sette et al. (2015). The authors also found an increase in the phenolic content of the OS during the OD of raspberry. Moreover, the mineral contents also showed slight increases in the OS during the reuse trial. As previously stated, minerals have high water solubility, and the main variation was observed with potassium, the most abundant mineral in the fruit (Table 1). According to Peiró-Mena et al. (2007), there was also an increase in the mineral contents of the OS during reuse in pineapple OD.

Regarding the count of spoilage microorganisms (yeasts and molds), the microbial load of the system remained low throughout the trial (Table 4). The spoilage microflora of the syrup was maintained at the minimal count according to the detection method $\left(<10 \mathrm{CFU} \mathrm{g}^{-1}\right)$. The cause might be the high concentration $\left(60-65^{\circ}\right.$ Brix) and low $\mathrm{pH}(<4.5)$ of the OS. Additionally, the heat treatment during the concentration operation (approximately $70^{\circ} \mathrm{C}$ for $5 \mathrm{~min}$ ), in the middle of the trial, might have had a lethal effect, reducing the microbial load. Besides, the fruit microbial load showed a reduction in each OD cycle, especially after the third one, probably due to the decrease in the $\mathrm{pH}$.

During the panning process, a good adherence of the fruit powder to the centers was observed, resulting in a dragée with uniform and compact coating. This result showed the viability of applying the $\mathrm{OS}_{\mathrm{rf}}$ as an adhesion solution. The weight gain with coating was of

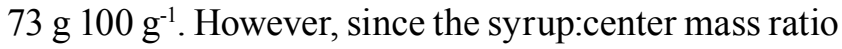

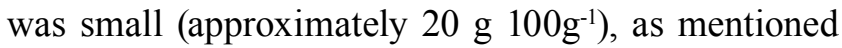
before, the contribution of the $\mathrm{OS}_{\mathrm{rf}}$ with nutrients

Table 4. Yeast and mold counts in the initial syrup $\left(\mathrm{S}_{\mathrm{i}}\right)$, fresh fruit (FF), and osmodehydrated fruit (OF) in three cycles of the pineapple (Ananas comosus) osmotic dehydration trial ${ }^{(1)}$.

\begin{tabular}{lccccccc}
\hline Cycle & \multicolumn{3}{c}{ Mold count $\left(\mathrm{CFU} \mathrm{g}{ }^{-1}\right)$} & & \multicolumn{3}{c}{ Yeast count $\left(\mathrm{CFU} \mathrm{g} \mathrm{g}^{-1}\right)$} \\
\cline { 2 - 4 } \cline { 6 - 7 } & $\mathrm{FF}$ & $\mathrm{OF}$ & $\mathrm{S}_{\mathrm{i}}$ & & $\mathrm{FF}$ & $\mathrm{OF}$ & $\mathrm{S}_{\mathrm{i}}$ \\
\hline 1 & $6.3 \times 10^{2}$ & $7.6 \times 10^{2}$ & $<10$ & & $1.3 \times 10^{3}$ & $1.0 \times 10^{3}$ & $<10$ \\
3 & $2.6 \times 10^{4}$ & $40(\mathrm{est}) \mathrm{a}^{(1)}$ & $<10$ & & $1.7 \times 10^{5}$ & $2.9 \times 10^{3}$ & $<10$ \\
5 & $1.0 \times 10^{2}$ & $<10^{2}$ & $<10$ & & $2.4 \times 10^{3}$ & $6 \times 10^{2}(\mathrm{est})^{(1)}$ & $90(\mathrm{est})^{(1)}$ \\
\hline
\end{tabular}

${ }^{(1)}$ Estimated count for the quantification limit of the adopted method. to the product might have been low. Therefore, it is reasonable to expect that the nutrients of the dragée (Table 5) originated mostly from fruit powder and dried pineapple. An assessment of the composition of the used ingredients may help to understand the final nutritional quality obtained. Regarding polyphenols, acai pulp may have up to $180 \mathrm{mg}$ GAE $100 \mathrm{~g}^{-1}$ (Paz et al., 2015). Strawberry, grape, and blackberry may also be considered sources of phenolics, with contents of $132.1,117.1$, and $118.9 \mathrm{mg} 100 \mathrm{~g}^{-1}$, respectively (Kuskoski et al., 2006). Strawberry is a good source of vitamin C (58.8 mg $\left.100 \mathrm{~g}^{-1}\right)$, followed by pineapple (34.6 $\left.\mathrm{mg} 100 \mathrm{~g}^{-1}\right)$. Regarding minerals, the following fruits stand out: grape, with $203 \mathrm{mg} 100 \mathrm{mg}^{-1}$ potassium;

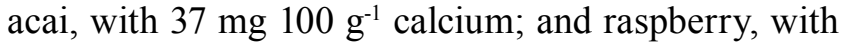

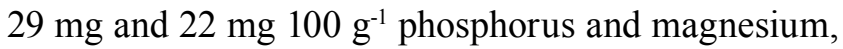
respectively (Lima et al., 2011; USDA, 2016).

In the sensory evaluation, the attribute flavor stood out with mean acceptance close to "like very much" in the adopted scale (Figure 1). In contrast, the score of the attribute texture was close to "like slightly"; however, the intention to purchase was "probably would buy". According to the responses, the most appreciated aspects were overall flavor, followed by the intense/natural flavor of pineapple. The least appreciated characteristic was texture; however, some adjustments may easily be implemented in the OD process aiming at a crispier texture. As a whole, the

Table 5. Physicochemical properties of the fruit snack formulated with the pineapple (Ananas comosus) osmotic solution ${ }^{(1)}$.

\begin{tabular}{|c|c|}
\hline Property & Fruit snack \\
\hline Moisture content $\left(\mathrm{g} 100 \mathrm{~g}^{-1}\right)$ & $13.82 \pm 0.08$ \\
\hline Water activity & $0.675 \pm 0.004$ \\
\hline Total carotenoids $\left(\mu \mathrm{g} 100 \mathrm{~g}^{-1}\right)^{(2)}$ & $220.00 \pm 0.01$ \\
\hline Total polyphenols (mg GAE $100 \mathrm{~g}^{-1}$ ) & $153.64 \pm 0.37$ \\
\hline Vitamin C (mg $\left.100 \mathrm{~g}^{-1}\right)$ & $176.90 \pm 1.13$ \\
\hline Sodium (mg $\left.100 \mathrm{~g}^{-1}\right)$ & $16.70 \pm 0.50$ \\
\hline Calcium (mg $100 \mathrm{~g}^{-1}$ ) & $44.00 \pm 3.00$ \\
\hline Potassium (mg $100 \mathrm{~g}^{-1}$ ) & $333.00 \pm 10.00$ \\
\hline Copper (mg $\left.100 \mathrm{~g}^{-1}\right)$ & $0.23 \pm 0.02$ \\
\hline Iron $\left(\mathrm{mg} 100 \mathrm{~g}^{-1}\right)$ & $1.01 \pm 0.04$ \\
\hline Phosphorous (mg $100 \mathrm{~g}^{-1}$ ) & $27.00 \pm 1.00$ \\
\hline Magnesium (mg $\left.100 \mathrm{~g}^{-1}\right)$ & $133.00 \pm 5.00$ \\
\hline Manganese (mg $\left.100 \mathrm{~g}^{-1}\right)$ & $2.28 \pm 0.20$ \\
\hline Zinc (mg $\left.100 \mathrm{~g}^{-1}\right)$ & $0.26 \pm 0.02$ \\
\hline
\end{tabular}

${ }^{(1)}$ Mean \pm standard deviation $(\mathrm{n}=3) .{ }^{(2)}$ Expressed as $\beta$-carotene. 


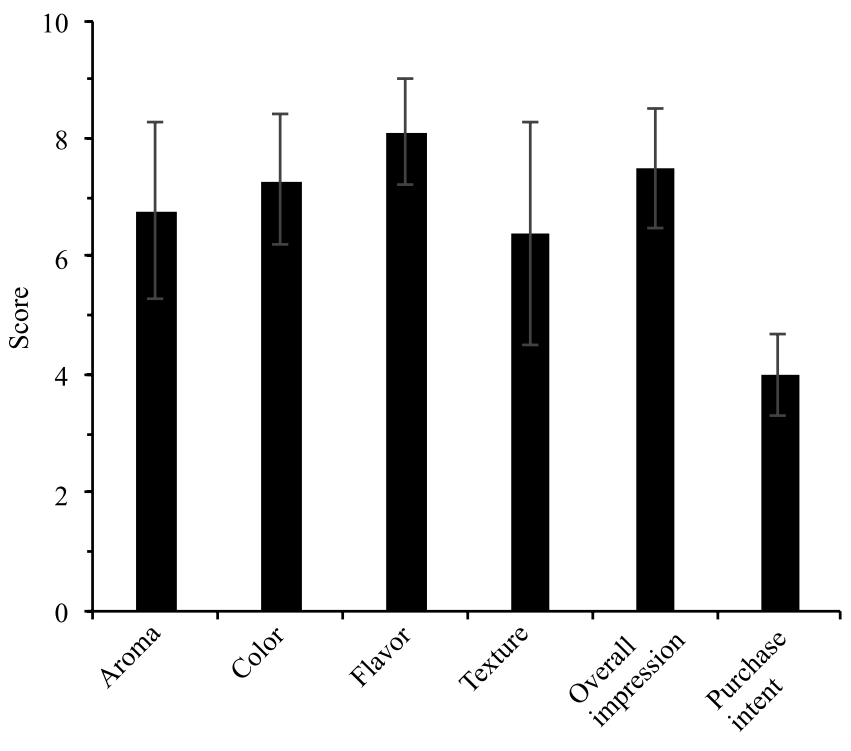

Figure 1. Means of the evaluated attributes in the sensory acceptance test and purchase intent evaluation for pineapple (Ananas comosus) snack covered with red fruit and acai (Euterpe oleracea) powders.

result is encouraging since the obtained fruit dragée is a new concept.

\section{Conclusions}

1. Reusing sucrose syrup in pineapple (Ananas comosus) osmotic dehydration is technically feasible for five consecutive cycles with only one intermediate reconditioning operation.

2. The spent solution is rich in vitamin $\mathrm{C}$ and potassium, with intermediate concentrations of phenolics and carotenoids, and traces of other minerals, such as calcium, magnesium, and phosphorus.

3. In panning, the osmotic solution allows the adhesion of the acai and red fruit powders to the dried pineapple, used as the center, resulting in a product with high nutrient contents and great sensory acceptance.

\section{Acknowledgments}

ToConselho Nacional de DesenvolvimentoCientífico e Tecnológico (CNPq, Process No. 310254/2011-6) and to Fundação de Amparo à Pesquisa do Estado de São Paulo (Fapesp, Process No. 2012/24117-1), for financial support.

\section{References}

AACHARY, A.A.; PRAPULLA, S.G. Value addition to spent osmotic sugar solution (SOS) by enzymatic conversion to fructooligosaccharides (FOS), a low calorie prebiotic. Innovative Food Science and Emerging Technologies, v.10, p.284-288, 2009. DOI: 10.1016/J.IFSET.2008.11.013.

ARAYA-FARIAS, M.; MACAIGNE, O.; RATTI, C. On the development of osmotically dehydrated seabuckthorn fruits: pretreatments, osmotic dehydration, postdrying techniques, and nutritional quality. Drying Technology, v.32, p.813-819, 2014. DOI: $10.1080 / 07373937.2013 .866143$.

BENASSI, M.T.; ANTUNES, A.J. A comparison of metaphosphoric and oxalic acids as extractants solutions for the determination of vitamin $\mathrm{C}$ in selected vegetables. Arquivos de Biologia e Tecnologia, v.31, p.507-513, 1988.

BENVENUTI, S.; PELLATI, F.; MELEGARI, M.; BERTELLI, D. Polyphenols, anthocyanins, ascorbic acid, and radical scavenging activity of Rubus, Ribes, and Aronia. Journal of Food Science, v.69, p.164-169, 2004. DOI: 10.1111/J.1365-2621.2004.TB13352.X.

BLANDA, G.; CERRETANI, L.; BENDINI, A.; CARDINALI, A.; SCARPELLINI, A.; LERCKER, G. Effect of vacuum impregnation on the phenolic content of Granny Smith and Stark Delicious frozen apple $c v v$. European Food Research and Technology, v.226, p.1229-1237, 2008. DOI: 10.1007/s00217-0070624-x.

CARVALHO, P.R.N.; COLLINS, C.H.; RODRIGUEZ-AMAYA, D.B. Comparison of provitamin A determination by normalphase gravity-flow chromatography and reversed-phase high performance liquid chromatography. Chromatographia, v.33, p.133-137, 1992. DOI: 10.1007/BF02275893.

CHANDRA, S.; KUMARI, D. Recent development in osmotic dehydration of fruit and vegetables: a review. Critical Reviews in Food Science and Nutrition, v.55, p.552-561, 2015. DOI: 10.1080/10408398.2012.664830.

DALLA ROSA, M.; GIROUX, F. Osmotic treatments (OT) and problems related to the solution management. Journal of Food Engineering, v.49, p.223-236, 2001. DOI: 10.1016/S02608774(00)00216-8.

DOWNES, F.P.; ITO, K. (Ed.). Compendium of methods for the microbiological examination of foods. $4^{\text {th }}$ ed. Washington: APHA, 2001. 676p. DOI: 10.2105/9780875531755.

FAO. Food and Agriculture Organization of the United Nations. Faostat. 2016. Available at: <http://faostat.fao.org $>$. Accessed on: Mar. 152016.

GERMER, S.P.M.; QUEIROZ, M.R. de; AGUIRRE, J.M.; BERBARI, S.A.; SILVEIRA, N.F. de A. Reuse of sucrose syrup in the osmotic dehydration of peaches. Drying Technology, v.30, p.1532-1540, 2012. DOI: 10.1080/07373937.2012.694945.

GERMER, S.P.M.; SOUZA, E. de C.G.; MORGANO, M.A.; SILVA, M.G. da; SILVEIRA, N.F. de A. Effect of reconditioning and reuse of sucrose syrup in quality properties and retention of nutrients in osmotic dehydration of guava. Drying Technology, v.34, p.997-1008, 2016. DOI: 10.1080/07373937.2015.1090446. 
HORWITZ, W.; LATIMER JR., G.W. (Ed.). Official Methods of Analysis of AOAC International. $18^{\text {th }}$ ed., rev. 3. Gaithersburg: Association of Official Analytical Chemists, 2010.

KHOO, H.-E.; PRASAD, K.N.; KONG, K.-W.; JIANG, Y.; ISMAIL, A. Carotenoids and their isomers: color pigments in fruits and vegetables. Molecules, v.16, p.1710-1738, 2011. DOI: 10.3390/molecules16021710.

KITT, J.S. Introduction to panning. In: PMCA. back to basics: confectionery fundamentals: volume 1: 2000-2006. Bethlehem, 2007. p.191-196.

KUCNER, A.; KLEWICKI, R.; SÓJKA, M. The influence of selected osmotic dehydration and pretreatment parameters on dry matter and polyphenol content in highbush blueberry (Vaccinium corymbosum L.) fruits. Food and Bioprocess Technology, v.6, p.2031-2047, 2013. DOI: 10.1007/s11947-012-0997-0.

KUSKOSKI, E.M.; GARCÍA ASUERO, A.; MORALES, M.T.; FETT, R. Frutos tropicais silvestres e polpas de frutas congeladas: atividade antioxidante, polifenóis e antocianinas. Ciência Rural, v.36, p.1283-1287, 2006. DOI: 10.1590/S010384782006000400037.

LIMA, D.M.; PADOVANI, R.M.; RODRIGUEZ-AMAYA, D.B.; FARFÁN, J.A.; NONATO, C.T.; LIMA, M.T. de. Tabela brasileira de composição de alimentos. 4.ed. rev. e ampl. Campinas: Nepa, Unicamp, 2011. 161p.

LOWITHUN, N.; CHAROENREIN, S. Influence of osmodehydrofreezing with different sugars on the quality of frozen rambutan. International Journal of Food Science and Technology, v.44, p.2183-2188, 2009. DOI: 10.1111/j.13652621.2009.02058.x.

MEIlGAARD, M.C.; CIVILle, G.V.; CARR, B.T. Sensory evaluation techniques. $4^{\text {th }}$ ed. Boca Raton: CRC Press, 2006. $464 \mathrm{p}$.

NOWACKA, M.; TYLEWICZ, U.; LAGHI, L.; ROSA, M.D.; WITROWA-RAJCHERT, D. Effect of ultrasound treatment on the water state in kiwifruit during osmotic dehydration. Food Chemistry, v.144, p.18-25, 2014. DOI: 10.1016/j. foodchem.2013.05.129.

OSORIO, C.; FRANCO, M.S.; CASTAÑO, M.P.; GONZÁLEZMIRET, M.L.; HEREDIA, F.J.; MORALES, A.L. Colour and flavour changes during osmotic dehydration of fruits. Innovative Food Science and Emerging Technologies, v.8, p.353-359, 2007. DOI: 10.1016/j.ifset.2007.03.009.
PAZ, M.; GÚLLON, P.; BARROSO, M.F.; CARVALHO, A.P.; DOMINGUES, V.F.; GOMES, A.M.; BECKER, H.; LONGHINOTTI, E.; DELERUE-MATOS, C. Brazilian fruit pulps as functional foods and additives : evaluation of bioactive compounds. Food Chemistry, v.172, p.462-468, 2015. DOI: 10.1016/j.foodchem.2014.09.102.

PEIRÓ-MENA， R.; CAMACHO, M.M.; MARTÍNEZNAVARRETE, N. Compositional and physicochemical changes associated to successive osmodehydration cycles of pineapple (Ananas comosus). Journal of Food Engineering, v.79, p.842849, 2007. DOI: 10.1016/j.jfoodeng.2006.03.004.

RODRIGUEZ-AMAYA, D.B. A guide to carotenoid analysis in foods. Washington: ILSI, 2001. 64p.

SANTOS, P.H.S.; SILVA, M.A. Retention of vitamin C in drying processes of fruits and vegetables - a review. Drying Technology, v.26, p.1421-1437, 2008. DOI: 10.1080/07373930802458911.

SETTE, P.A.; FRANCESCHINIS, L.E.; SCHEBOR, C.; SALVATORI, D. Osmotic dehydrated raspberries: changes in physical aspects and bioactive compounds. Drying Technology, v.33, p.659-670, 2015. DOI: 10.1080/07373937.2014.971123.

SUN-WATERHOUSE, D. The development of fruit-based functional foods targeting the health and wellness market: a review. International Journal of Food Science and Technology, v.46, p.899-920, 2011. DOI: 10.1111/J.1365-2621.2010.02499.X.

USDA. United States Department of Agriculture. USDA food composition databases. Available at: $<$ https://ndb.nal.usda.gov/ $\mathrm{ndb} /$ search/list?qlookup $=\& \mathrm{qt}=\& \mathrm{manu}=\& \mathrm{SYNCHRONIZER}$ URI $=\% 2$ Fndb $\% 2$ Fse arch $\% 2$ Flist\&SYNCHRONIZER TOKEN=5086f5e1-d0c6-499e-b9bb-d7d1b6090e8>. Accessed on: July 22016.

VALDEZ-FRAGOSO, A.; MUJICA-PAZ, H.; GIROUX, F.; WELTI-CHANES, J. Reuse of sucrose syrup in pilot-scale osmotic dehydration of apple cubes. Journal of Food Process Engineering, v.25, p.125-139, 2002. DOI: 10.1111/j.17454530.2002.tb00559.x.

VIEIRA, G.S.; PEREIRA, L.M.; HUBINGER, M.D. Optimisation of osmotic dehydration process of guavas by response surface methodology and desirability function. International Journal of Food Science and Technology, v.47, p.132-140, 2012. DOI: 10.1111/j.1365-2621.2011.02818.x.

YADAV, A.K.; SINGH, S.V. Osmotic dehydration of fruits and vegetables: a review. Journal of Food Science and Technology, v.51, p.1654-1673, 2014. DOI: 10.1007/s13197-012-0659-2.

Received on September 5, 2016 and accepted on March 6, 2017 